\title{
PERBANDINGAN HASIL BELAJAR ANTARA MODEL PEMBELAJARAN MEANS- ENDS ANALYSIS (MEA) DENGAN PEMBELAJARAN EKSPOSITORI
}

\author{
${ }^{1}$ Apri Susanti , ${ }^{2}$ Agus Susanta, ${ }^{3}$ Effie Efrida Muchlis \\ ${ }_{1}^{123}$ Program Studi Pendidikan Matematika, FKIP Universitas Bengkulu \\ Email : 1 aprisusanti97@gmail.com, ${ }^{2}$ agusunib@gmail.com, ${ }^{3}$ effieefrida@gmail.com
}

\begin{abstract}
Abstrak
Penelitian ini bertujuan untuk mengetahui apakah hasil belajar peserta didik yang menggunakan model pembelajaran Means-Ends Analysis (MEA) lebih baik dari pada hasil belajar peserta didik yang menggunakan pembelajaran ekspositori. Penelitian ini merupakan penelitian eksperimen semu (Quasy Experiment). Populasi penelitian ini adalah seluruh peserta didik kelas VII SMP Negeri 1 Bengkulu Tengah semester genap tahun ajaran 2017/2018. Sampel penelitian diambil dengan menggunakan teknik purposive sampling, sampel dalam penelitian ini adalah peserta didik kelas VII 8 sebagai kelas eksperimen dengan menerapkan model pembelajaran means-ends analysis dan kelas VII 9 sebagai kelas kontrol dengan menerapkan pembelajaran ekspositori. Instrumen yang digunakan untuk pengumpulan data dalam penelitian ini adalah lembar tes. Untuk uji hipotesis digunakan uji-t untuk sampel independen dengan data berdistribusi normal dan homogen. Nilai rata-rata kelas eksperimen adalah 55,19 dan nilai rata-rata kelas kontrol adalah 42,79. Dari hasil penelitian diperoleh nilai rata-rata kelas eksperimen lebih tinggi dari nilai rata-rata kelas kontrol. Kemudian dari perhitungan uji-t diketahui nilai $t_{\text {hitung }}=2,242$ sedangkan nilai $t_{\text {tabel }}=2,000$. Nilai $t_{\text {hitung }}$ lebih dari nilai $t_{\text {tabel }}$ sehingga $\mathrm{H}_{0}$ ditolak dan dapat disimpulkan hasil belajar peserta didik yang menggunakan model pembelajaran Means-Ends Analysis (MEA) lebih baik dari pada hasil belajar peserta didik yang menggunakan pembelajaran ekspositori.
\end{abstract}

Kata kunci : Hasil Belajar, Means-Ends Analysis (MEA), Ekspositori

\begin{abstract}
The purpose of this research was to investigate whether the learning outcome of students in math used Means-Ends Analysis (MEA is more than the learning out come of students used expository learning in first grade of Junior High School 1 Bengkulu tengah. This research used a quasy-experimental method (Quasy Experiment). The population of research was in first grade of Junior High School number 1 Bengkulu Tengah in the academic year 2017/2018. The sample in this research took by using purposive sampling, the class VII 8 as experiment class who received treatment of means-ends analysis learning and class VII 9 as control class who received treatment of exspository learning. The data collection techniques used an instrument test of learning outcome in the form of essays. From the results of the study obtained the average value of the experimental class is higher than the average value of the control class, then from the calculation of $t$-test is known $t$-hitung $=2,242$ while $t$-tabel $=2,000$. The value of $t$ count is more than $t$-tabel value so that $H_{0}$ is rejected and it can be concluded that student learning result using Means-Ends Analysis (MEA) learning model is better than student study's result using expository learning.
\end{abstract}

Keywords : Study's result, Means-Ends Analysis (MEA), Expository

\section{PENDAHULUAN}

Matematika adalah dasar dari semua ilmu sehingga banyak ilmu-ilmu yang penemuan dan pengembangannya tergantung dari matematika. Matematika merupakan mata pelajaran yang wajib dipelajari oleh semua peserta didik sejak SD sampai perguruan tinggi. Melalui pembelajaran matematika diharapkan peserta didik dapat menumbuhkan

Apri, Agus, Effie

Perbandingan Hasil Belajar Antara Model Pembelajaran Means-Ends Analysis (MEA) Dengan Pembelajaran Ekspositori 
kemampuan berpikir kritis, logis, sistematis, dan cermat dalam memecahkan masalah. Meskipun matematika memiliki peran yang sangat penting dalam ranah pendidikan namun pada kenyataannya banyak orang yang menganggap matematika sebagai salah satu mata pelajaran yang sulit.

Pada pembelajaran matematika di SMP sering dijumpai peserta didik yang mengalami kesulitan dalam memahami materi yang diajarkan sehingga mengakibatkan hasil belajar yang diperolehpun rendah. Kesulitan yang dihadapi peserta didik dalam memahami materi matematika bisa disebabkan oleh beberapa faktor, yaitu faktor internal (dari dalam diri peserta didik) dan faktor eksternal (dari luar diri peserta didik). Salah satu faktor yang berasal dari luar diri peserta didik yang mempengaruhi hasil belajar peserta didik adalah proses pembelajaran matematika yang kurang tepat.

Berdasarkan wawancara dengan salah satu guru matematika kelas VII SMP Negeri 1 Bengkulu Tengah diperoleh informasi bahwa pembelajaran yang dilakukan masih berpusat pada guru. Guru menyiapkan materi dan contoh soal untuk disampaikan didepan kelas, sedangkan peserta didik duduk, mendengarkan lalu mencatat semua materi yang disajikan. Ketika guru mempersilahkan peserta didik untuk bertanya jika ada penjelasan yang belum dipahami, hanya beberapa peserta didik yang bertanya. Tetapi pada saat guru memberikan latihan, ternyata hanya sebagian peserta didik yang mengerjakan sendiri, sedangkan peserta didik yang lain hanya menunggu hasil pekerjaan temannya. Sikap pasif yang dimiliki peserta didik tersebut disebabkan karena proses pembelajaran yang kurang menarik dan rendahnya kemampuan peserta didik dalam memahami isi dari soal yang diberikan.

Pada pelajaran matematika, kemampuan pemecahan masalah yang dimiliki peserta didik kelas VII masih tergolong rendah. Hal ini dapat dilihat dari hasil pengerjaan soal yang berbentuk soal cerita, masih banyak peserta didik belum bisa menyelesaikan permasalahan yang terdapat pada soal. Peserta didik kurang bisa memahami masalah, merancanakan penyelesaian, sampai dengan menemukan solusi dan hasil akhirnya. Padahal kemampuan pemecahan masalah dalam matematika merupakan hal penting yang harus dimiliki dan dikembangkan oleh semua peserta didik. Pada pelajaran matematika peserta didik perlu dibiasakan untuk memecahkan masalah dan mengeluarkan ide-ide mereka sebagai solusi dari masalah yang dihadapi, supaya kemampuan pemecahan masalah peserta didik meningkat dan peserta didik menjadi berperan aktif dalam proses pembelajaran, maka guru harus menggunakan model pembelajaran yang dapat memperbaiki proses pembelajaran dan meningkatkan kemampuan pemecahan masalah.

Model pembelajaran yang dapat diterapkan untuk membuat peserta didik aktif dan meningkatkan kemampuan pemecahan masalah salah satunya adalah model pembelajaran means-ends analysis (MEA). Means-Ends Analysis (MEA) merupakan pengembangan suatu jenis pemecahan masalah dengan berdasarkan suatu strategi yang membantu peserta didik dalam menemukan cara penyelesaian masalah melalui penyederhanaan masalah yang berfungsi sebagai petunjuk dalam menetapkan cara yang paling efektif dan efisien untuk memecahkan masalah yang dihadapi (Shoimin, 2014:55). Pembelajaran dengan model MEA menuntut peserta didik untuk berpartisipasi aktif dalam kegiatan belajar mengajar, sehingga peserta didik yang lebih dominan berperan aktif dalam proses pembelajaran, sedangkan guru hanya berperan sebagai fasilitator dan motivator. Materi pembelajaran tidak disajikan dalam bentuk jadi, tetapi harus merupakan temuan dari peserta didik sehingga pembelajaran akan semakin bermakna.

Berdasarkan uraian diatas maka peneliti tertarik melakukan penelitian yang bejudul "Perbandingan Hasil Belajar Antara Model Pembelajaran Means-Ends Analysis (MEA) Dengan Pembelajaran Ekspositori Di Kelas VII SMP Negeri 1 Bengkulu Tengah". 


\section{METODE}

Jenis penelitian yang digunakan pada penelitian ini adalah Quasi Experiment atau eksperimen semu. Populasi dalam penelitian ini adalah seluruh peserta didik kelas VII SMP Negeri 1 Bengkulu Tengah tahun ajaran 2017/2018. Sampel dalam penelitian ini ditentukan dengan teknik purposive sampling. Purposive sampling adalah teknik penentuan sampel berdasarkan kriteria tertentu (Martono, 2014:81). Sampel pada penelitian ini adalah kelas VII 8 sebagai kelas eksperimen dan VII 9 sebagai kelas kontrol

Instrumen yang digunakan pada penelitian ini berupa lembar tes akhir (posttest) yang berupa soal uraian atau essay. Sebelum digunakan sebagai soal posttest, instrument test terlebih dahulu divalidasi oleh ahli kemudian diuji cobakan pada kelas uji coba. Data hasil uji coba selanjutnya dianalisis dengan menggunakan uji validitas empiris, uji reliabilitas, uji taraf kesukaran, dan uji daya pembeda soal, pengujian ini bertujuan untuk mengetahui kelayakkan butir soal yang akan digunakan sebagai instrument posttest pada penelitian.

\section{Uji Validitas empiris}

Uji validitas empiris dilakukan dengan menggunakan rumus korelasi product moment.

$$
r_{x y}=\frac{N \sum X Y-\left(\sum X\right)\left(\sum Y\right)}{\sqrt{\left\{N \sum X^{2}-\left(\sum X^{2}\right)\right\}\left\{N \sum Y^{2}-\left(\sum Y^{2}\right)\right\}}}
$$

\section{Uji reliabilitas}

(Sugiyono, 2017:228)

Pada penelitian ini rumus yang digunakan untuk mengukur reliabilitas instrumen adalah rumus Alpha, yaitu :

$$
r_{11}=\left[\frac{k}{k-1}\right]\left[1-\frac{\sum \sigma_{h}^{2}}{\sigma_{t}^{2}}\right]
$$

(Siregar, 2014:176)

\section{Uji taraf kesukaran}

Pada penelitian ini rumus yang digunakan untuk menentukan taraf kesukaran soal adalah sebagai berikut:

$$
I K=\frac{\bar{X}}{S M I}
$$

\section{Uji daya pembeda soal}

(Lestari dan Yudhanegara,2017:224)

Pada penelitian ini rumus daya pembeda soal yang digunakan adalah sebagai berikut:

$$
D P=\frac{\bar{X}_{A}-\bar{X}_{B}}{S M I}
$$

(Lestari dan Yudhanegara,2017:217)

Setelah dilakukan uji kelayakkan soal maka selanjutnya dilakukan posttes dikelas eksperimen dan dikelas kontrol. Data hasil posttest kemudian dianalisis dengan menggunakan uji Normalitas, uji Homogenitas, dan uji hipotesis.

\section{Uji normalitas}

Untuk uji normalitas digunakan rumus chikuadrat, yaitu :

$$
\chi_{0}^{2}=\sum_{i=1}^{k} \frac{\left(f_{0}-f_{h}\right)^{2}}{f_{h}}
$$

(Sugiyono, 2012:19)

\section{Uji homogenitas}

Untuk uji homogenitas varians digunakan rumus uji fisher, yaitu:

$$
\mathrm{F}=\frac{\text { varians terbesar }}{\text { varians terkecil }}
$$

(Hasan, 2008:183)

\section{Uji hipotesis}

Untuk uji hipotesis jika data berdistribusi normal dan homogen digunakan rumus uji-t, yaitu:

$$
t=\frac{\bar{X}_{1}-\bar{X}_{2}}{\sqrt{\frac{\left(n_{1}-1\right) s_{1}^{2}+\left(n_{2}-1\right) s_{2}^{2}}{n_{1}+n_{2}-2}\left(\frac{1}{n_{1}}+\frac{1}{n_{2}}\right)}}
$$

(Sugiyono, 2017:138)

\section{HASIL DAN PEMBAHASAN}

Berdasarkan hasil tes akhir (posttest), diperoleh bahwa rata-rata hasil belajar peserta didik kelas eksperimen dengan menggunakan model pembelajaran means-ends analysis lebih tinggi dari rata-rata hasil belajar peserta didik

\section{Apri, Agus, Effie}


kelas kontrol dengan menggunakan model pembelajaran ekspositori. Nilai rata-rata pada kelas eksperimen adalah 55,19 sedangkan nilai rata-rata kelas kontrol adalah 42,79. Meskipun rata-rata kelas eksperimen lebih tinggi dari kelas kontrol, tetapi rata-rata nilai pada kelas eksperimen berada dibawah kriteria ketuntasan minimum (KKM). Hal ini disebabkan karena faktor-faktor, yaitu pertama, pada saat mengerjakan LKPD jumlah peserta didik dalam 1 kelompok terdiri dari 4 orang peserta didik. namun peserta didik kurang bekerja sama antar anggota kelompoknya, sehingga yang menuliskan jawaban LKPD hanya 1 orang. Peserta didik yang mampu memecahkan masalah hanya peserta didik yang mengerjakan LKPD tersebut.

Kedua, setelah melihat pertemuan pertama dan kedua banyak peserta didik yang tidak bekerja maka pada pertemuan selanjutnya peneliti meminta masing-masing peserta didik mengerjakan satu soal yang terdapat pada LKPD. Hal ini dilakukan oleh peneliti dengan maksud agar semua peserta didik terlatih dalam memecahkan suatu masalah. Namun karena 1 orang hanya mengerjakan 1 soal maka yang terjadi adalah peserta didik tersebut kurang terlatih memecahkan masalah karena sedikitnya latihan dalam memecahkan masalah. Inilah yang menjadi penyebab nilai rata-rata posttest pada kelas eksperimen belum mencapai KKM. Berikut analisis perbandingan jawaban soal posttest peserta didik berdasarkan rata-rata skor persoal.

Tabel 4. 10 Analisis Rata-rata Skor Persoal

\begin{tabular}{|c|c|c|c|}
\hline No & $\begin{array}{c}\text { Kelas } \\
\text { Eksperimen }\end{array}$ & $\begin{array}{c}\text { Kelas } \\
\text { Kontrol }\end{array}$ & Selisih \\
\hline 1. & 4,15 & 3,63 & 0,52 \\
\hline 2. & 10,88 & 8,97 & 1,91 \\
\hline 3. & 7,92 & 4,96 & 2,96 \\
\hline 4. & 9,04 & 5,63 & 3,41 \\
\hline 5. & 6,81 & 5,70 & 1,11 \\
\hline 6. & 8,88 & 6,93 & 1,95 \\
\hline 7. & 4,31 & 3,93 & 0,38 \\
\hline 8. & 3,19 & 3,04 & 0,15 \\
\hline
\end{tabular}

Sumber: Hasil Penelitian
Pada tabel diatas dapat kita lihat bahwa dari keseluruhan soal kelas eksperimen memiliki rata-rata skor persoal lebih tinggi dibandingkan kelas kontrol. Selisih rata-rata skor yang tinggi antara kelas eksperimen dan kelas kontrol berada pada soal nomor 3 dan nomor 4, sedangkan yang memiliki selisih ratarata yang rendah berada pada soal nomor 1,7 dan 8 . Rendahnya rata-rata skor soal nomor 3 pada kelas kontrol disebabkan karena dari 27 peserta didik yang mengikuti posttest hanya 1 peserta didik yang mampu menjawab pertanyaan dengan lengkap sehingga mendapatkan nilai maksimum, Sedangkan pada kelas eksperimen dari 26 peserta didik yang mengikuti posttest ada 5 peserta didik yang mampu menjawab pertanyaan dengan lengkap. Berikut gambar salah satu jawaban nomor 3 pada kelas eksperimen.

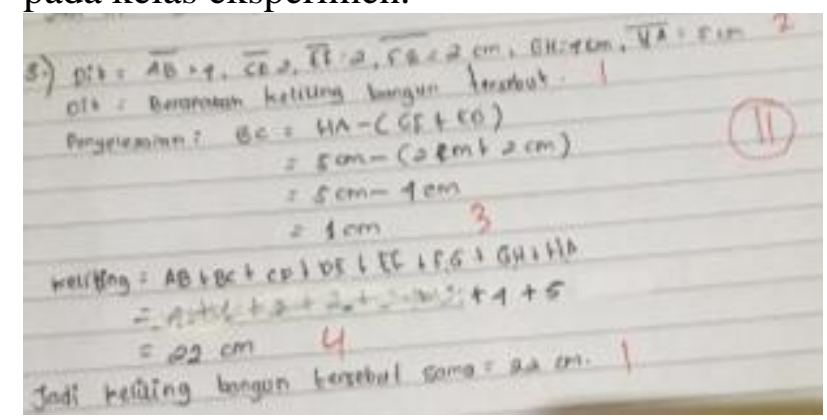

Gambar 4.10 Jawaban Soal Nomor 3 Pada Kelas Eksperimen

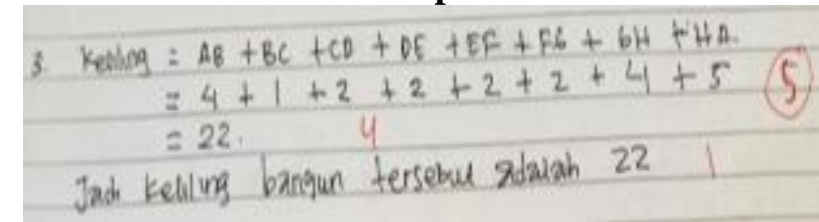

Gambar 4.11 Jawaban Soal Nomor 3 Pada Kelas Kontrol

Pada gambar 4.11 terlihat bahwa peserta didik belum merumuskan apa yang diketahui dan apa yang ditanya dari soal. Kemudian peserta didik juga tidak menuliskan cara memperoleh hal yang diperlukan, yang mana pada soal ini hal yang diperlukan untuk mencari keliling bangun tersebut adalah panjang BC. Tetapi pada gambar diatas peserta didik sudah menuliskan kesimpulan penyelesaian dari masalah, yaitu keliling bangun tersebut adalah 22 .

\section{Apri, Agus, Effie}

Perbandingan Hasil Belajar Antara Model Pembelajaran Means-Ends Analysis (MEA) Dengan Pembelajaran Ekspositori 
Pada soal nomor 4 rata-rata skor kelas kontrol dan kelas eksperimen memiliki selisih yang paling tinggi. Kelas kontrol memiliki ratarata skor dibawah kelas eksperimen, ini disebabkan karena pada kelas kontrol hanya ada 2 peserta didik yang menjawab pertanyaan dengan lengkap dan mendapatkan nilai maksimum, sedangkan pada kelas eksperimen ada 10 orang yang mampu menjawab dengan lengkap. Dari 10 orang yang menjawab dengan lengkap dapat dilihat bahwa pada kelas eksperimen ternyata lebih banyak peserta didik yang sudah terbiasa menyelesaikan masalah dengan langkah-langkah pemecahan masalah. Hal ini karena pada kelas eksperimen dengan menerapkan model means-ends analysis peserta didik dilatih untuk memecahkan masalah, yaitu merumuskan apa yang diketahui dan apa yang ditanya pada tahap mengidentifikasi perbedaan current state dan goal state, dan mengidentifikasi hal apa saja yang diperlukan pada tahap merumuskan subgoals, serta menuliskan cara penyelesaian, kesimpulan penyelesaian dari masalah pada tahap pemilihan operator atau solusi. Berikut gambar salah satu jawaban nomor 4 pada kelas eksperimen.

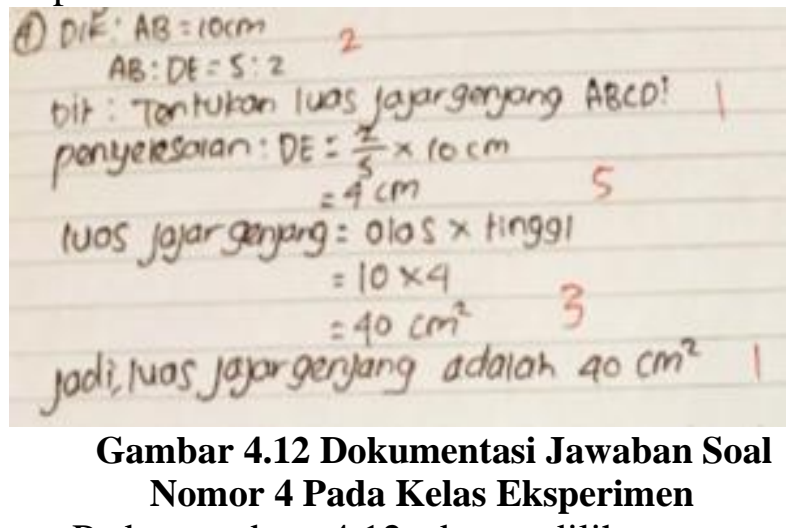

Pada gambar 4.12 dapat dilihat peserta didik merumuskan yang diketahui adalah panjang $\mathrm{AB}$ dan perbandingan $\mathrm{AB}: \mathrm{DE}=5: 2$ dan yang ditanya adalah luas jajargenjang ABCD. yang mana pada model means-ends analysis, merumuskan apa yang diketahui dan apa yang ditanya merupakan tahap mengidentifikasi perbedaan current state dan goal state, kemudian peserta didik juga merumuskan hal yang diperlukan untuk mencari luas jajargenjang adalah tinggi jajargenjang atau panjang $\mathrm{DE}$, bagian ini merupakan tahap merumuskan subgoals. selanjutnya peserta didik mencari panjang DE, setelah memperoleh panjang DE peserta didik mencari luas trapesium, dan juga menyimpulkan hasil akhir yang didapat, bagian ini merupakan tahap pemilihan operator atau solusi pada model means-ends analysis. Sedangkan pada kelas kontrol peserta didik belum terbiasa menyelesaikan masalah dengan tahap-tahap pemecahan masalah hal ini dapat terlihat pada soal nomor 4 hanya 2 peserta didik yang mampu menjawab dengan lengkap dan peserta didik yang lainnya banyak yang belum menjawab dengan lengkap. Berikut gambar salah satu jawaban peserta didik pada kelas kontrol.

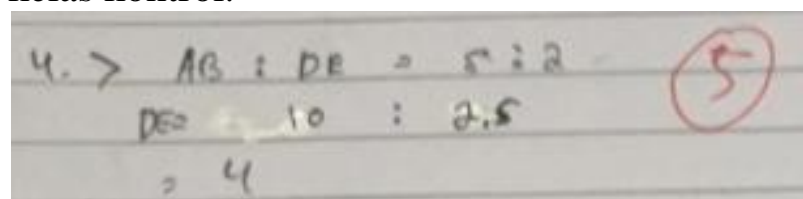

Gambar 4.13 Dokumentasi Jawaban Soal Nomor 4 Pada Kelas Kontrol

Pada gambar 4.13 terlihat bahwa peserta didik tidak menuliskan apa yang diketahui dan apa yang ditanya dari soal. Sehingga peserta didik tidak tau solusi akhir yang ingin diperoleh dari soal tersebut, seharusnya solusi akhir yang ingin diperoleh dari soal adalah luas jajargenjang tetapi peserta didik hanya mencari tinggi dari jajargenjang dan peserta didik tidak melanjutkan untuk mencari luas jajargenjang. Kesalahan peserta didik ini disebabkan karena peserta didik tidak menuliskan apa yang ditanyakan pada soal sehingga peserta didik pun tidak tau penyelesaian akhir yang diinginkan dari soal tersebut. Kemudian peserta didik juga tidak menuliskan kesimpulan akhir penyelesaian dari soal tersebut.

Selisih rata-rata skor persoal yang rendah berada pada soal nomor 1, 7 dan 8 . Rendahnya selisih pada soal nomor 1 disebabkan karena soal nomor 1 peserta didik hanya diminta untuk menyebutkan dan menggambarkan sebuah bangun datar sesuai dengan ciri-ciri yang telah

\section{Apri, Agus, Effie}

Perbandingan Hasil Belajar Antara Model Pembelajaran Means-Ends Analysis (MEA) Dengan Pembelajaran Ekspositori 
disebutkan pada soal. Sehingga banyak peserta didik pada kelas kontrol maupun kelas eksperimen yang mampu menjawab soal tersebut. Hal ini dapat dilihat pada kelas eksperimen dari 26 peserta didik, ada 13 orang yang mendapatkan skor maksimal, 7 peserta didik hampir menjawab dengan sempurna namun pada saat menggambar ada sedikit kekurangan, yaitu tidak membuat simbol bahwa semua sisi pada belah ketupat sama panjang sehingga skornya dikurangi 1 . Sedangkan 6 peserta didik hanya menjawab setengah dari pertanyaan tersebut, yaitu ada yang hanya menyebutkan nama bangun datarnya dan ada juga yang hanya menggambarkan bangun datarnya saja. Sehingga skor yang diperoleh berkurang. Kemudian pada kelas kontrol dari 27 peserta didik, ada 11 peserta didik yang mendapatkan skor maksimal, 4 peserta didik hampir menjawab dengan sempurna, 1 orang menjawab bahwa bangun datar segiempat yang memiliki keempat sisi sama panjang dan sudut yang berhadapan sama besar adalah persegi padahal jawaban yang benar adalah belah ketupat sehingga jawabanya salah mendapatkan skor 0 , dan 11 peserta didik hanya menjawab setengah dari pertanyaannya. Karena jumlah peserta didik yang mendapatkan skor maksimal dan peserta didik yang hanya menjawab setengah tidak jauh berbeda antara kelas ekperimen dan kelas kontrol maka rata-rata skor antara kedua kelas pun tidak jauh berbeda atau memilki selisih yang rendah.

Pada soal nomor 7 pada kelas eksperimen jumlah peserta didik yang menjawab dengan benar ada 9 peserta didik, jumlah peserta didik yang salah dalam mengoperasikan hasil akhirnya ada 2 peserta didik, sedangkan 15 peserta didik tidak menuliskan jawaban. Pada kelas kontrol ada 7 peserta didik yang menjawab dengan benar dan ada 7 peserta didik yang hanya membuat apa yang diketahui, apa yang ditanya, dan rumus dari luas layanglayang, 1 peserta didik salah dalam mengoperasikan hasil akhir, 2 peserta didik salah menuliskan jawaban dan 10 peserta didik tidak menuliskan jawaban. Karena jumlah peserta didik yang menjawab dengan benar pada kelas eksperimen dan kelas kontrol tidak jauh berbeda maka selisih rata-rata skor antara kedua kelas pun rendah. Berikut dokumentasi jawaban peserta didik pada kelas eksperimen.

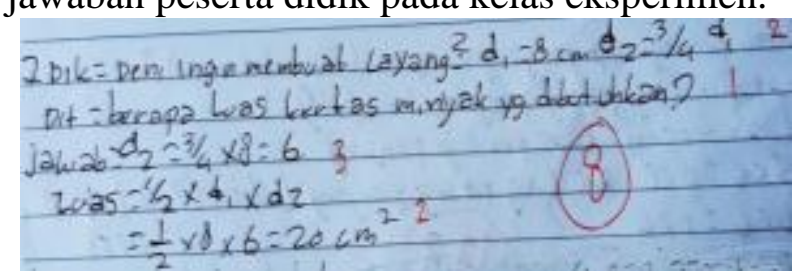

\section{Gambar 4.14 Dokumentasi Jawaban Soal Nomor 7 Pada Kelas Eksperimen}

Pada gambar 4.14 terlihat bahwa pada kelas eksperimen peserta didik sudah benar dalam merumuskan apa yang diketahui dan apa yang ditanya. Langkah-langkah yang dilakukan peserta didik juga sudah benar, hanya saja peserta didik salah pada saat mengoperasikan pada langkah terakhir sehingga jawaban akhir yang diperolehpun salah.

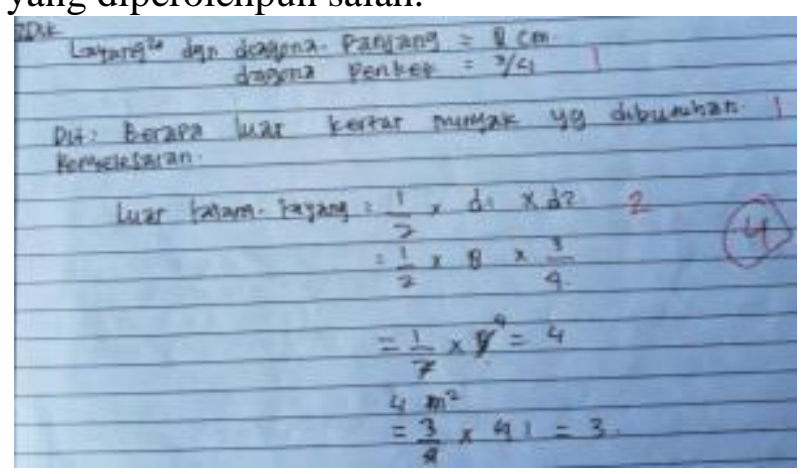

Gambar 4.15 Dokumentasi Jawaban Soal Nomor 7 Pada Kelas Kontrol

Pada gambar 4.15 terlihat bahwa pada kelas kontrol peserta didik sudah benar merumuskan apa yang ditanyakan, tetapi peserta didik belum tepat dalam merumuskan apa yang diketahui pada soal. Peserta didik kurang memahami informasi yang terdapat pada soal sehingga peserta didik tidak bisa menjawab pertanyaan dengan dengan benar. Peserta didik langsung memasukkan $\frac{3}{4}$ sebagai diagonal kedua kedalam rumus luas layanglayang, padahal pada soal dijelaskan bahwa diagonal pendek $\frac{3}{4}$ diagonal panjang atau diagonal kedua $=\frac{3}{4}$ diagonal pertama 
seharusnya peserta didik mencari panjang diagonal kedua terlebih dahulu, kemudian mencari luas layang-layang.

Pada soal nomor 8 kelas eksperimen dan kelas kontrol memiliki rata-rata skor tidak jauh berbeda karena pada kelas eksperimen hanya 5 peserta didik yang membuat gambar dari informasi yang ada pada soal, sehingga 5 peserta didik tersebut sudah melakukan langkah-langkah yang benar namun ada peserta didik yang salah mengoperasikan bilangan, 4 peserta didik menulis penyelesaiannya namun jawabanya salah hal ini karena peserta didik tidak membuat gambar dari informasi yang ada pada soal sehingga langkah-langkah penyelesaian yang dilakukan salah, dan 17 peserta didik tidak menuliskan jawaban.

Sedangkan pada kelas kontrol untuk soal nomor 8 ada 4 peserta didik yang membuat gambar dari informasi yang terdapat pada soal sehingga langkah-langkah penyelesaian yang dilakukan benar namun ada peserta didik yang salah mengoperasikan bilangan sehingga skor yang diperoleh berkurang dan 8 peserta didik menulis penyelesaian namun langkah-langkah penyelesaian yang dipilih salah hal ini disebabkan karena peserta didik tidak membuat gambar dari informasi yang ada. 3 peserta didik salah menuliskan jawaban dan 12 peserta didik tidak menuliskan jawaban.

Dari informasi tersebut dapat diketahui jumlah peserta didik yang menjawab dengan langkah-langkah yang benar pada kelas eksperimen dan kelas kontrol tidak jauh berbeda sehingga hal ini lah yang menyebabkan rata-rata skor kedua kelas memiliki selisih yang sangat rendah, namun pada kelas kontrol lebih banyak peserta didik yang menjawab dengan langkah-langkah yang salah hal ini karena pada kelas kontrol peserta didik belum terbiasa membuat sebuh gambar dari masalah yang terdapat pada soal tersebut. Berikut dokumentasi jawaban peserta didik pada kelas eksperimen.

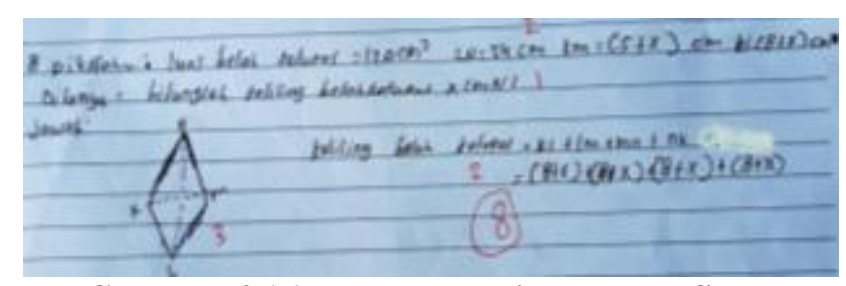

Gambar 4.16 Dokumentasi Jawaban Soal Nomor 8 Pada Kelas Eksperimen

Pada gambar 4.16 terlihat bahwa pada kelas eksperimen dalam menyelesaikan soal nomor 8 peserta didik membuat gambar belah ketupat KLMN, sehingga untuk mencari keliling belah ketupat tersebut peserta didik mengetahui bahwa keliling belah ketupat adalah jumlah dari sisi-sisinya, yaitu keliling $\mathrm{KLMN}=\mathrm{KL}+\mathrm{LM}+\mathrm{MN}+\mathrm{NK}$. Namun pada saat mencari keliling peserta didik terhenti karena peserta didik belum mencari nilai $\mathrm{x}$ dan peserta didik tidak mengetahui cara mencari nilai $\mathrm{x}$ sehingga peserta didik tidak dapatmenemukan solusi akhir dari masalah tersebut.

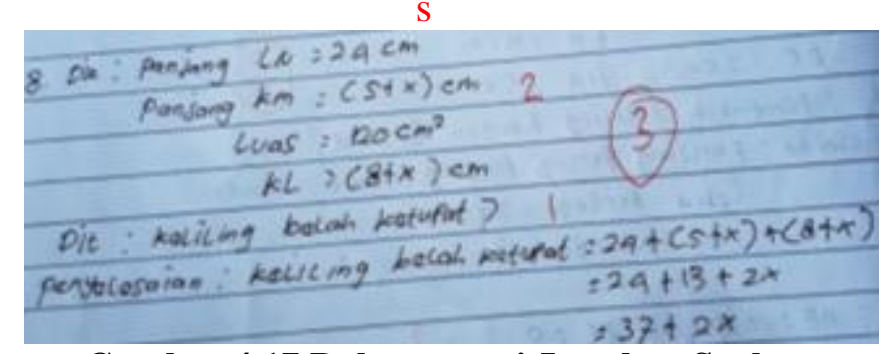

Gambar 4.17 Dokumentasi Jawaban Soal Nomor 8 Pada Kelas Kontrol

Pada gambar 4.17 terlihat bahwa pada kelas kontrol saat menyelesaikan masalah peserta didik tidak membuat gambar belah ketupat dari informasi yang ada pada soal sehingga peserta didik tidak tahu yang mana sisi-sisi dari belah ketupat. Pada saat mencari keliling peserta didik menjumlah panjang LN, $\mathrm{KM}$,dan KL, padahal apabila digambarkan belah ketupat KLMN, panjang LN dan KM merupakan diagonal belah ketupat dan bukan sisi belah ketupat.

Perbandingkan rata-rata skor setiap butir soal posttest pada kelas kontrol dan kelas eksperimen juga dapat dilihat pada diagram berikut:

\section{Apri, Agus, Effie}

Perbandingan Hasil Belajar Antara Model Pembelajaran Means-Ends Analysis (MEA) Dengan Pembelajaran Ekspositori 


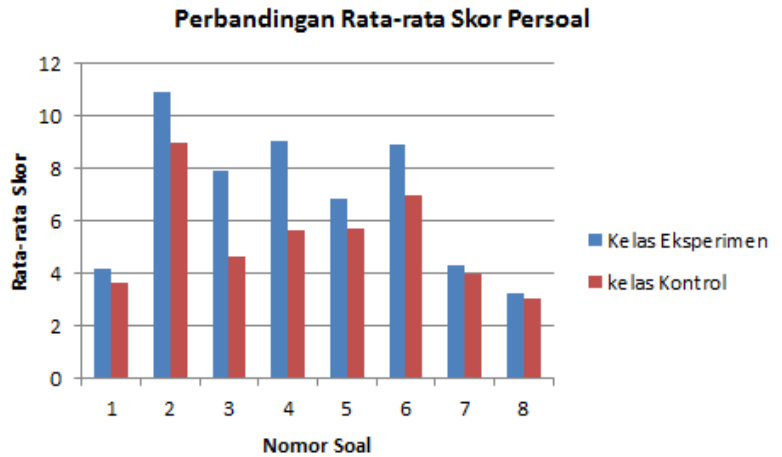

Gambar 4.18 Diagram Perbandingan Ratarata Skor Persoal

Hasil analisis jawaban soal posttest terlihat bahwa jumlah peserta didik yang menjawab dengan lengkap pada kelas eksperimen lebih banyak dibandingkan kelas kontrol, hal ini karena pada kelas eksperimen dengan menerapkan model means-ends analysis peserta didik sudah terbiasa menyelesaikan masalah dengan langkah-langkah pemecahan masalah

Pada model pembelajaran means-ends analysis siswa mengidentifikasi masalah seperti merumuskan apa yang diketahui dan apa yang ditanya dari suatu masalah, langkah ini terdapat pada tahap mengidentifikasi perbedaan current state dan goal state. Kemudian peserta didik juga sudah dibiasakan untuk membuat kesimpulan penyelesaian dari masalah yang terletak pada tahap pemilihan operator atau solusi,

Hal inilah yang membuat jumlah peserta didik yang menjawab dengan lengkap pada kelas eksperimen lebih banyak dibandingkan kelas kontrol. Sehingga dapat dikatakan bahwa model pembelajaran means-ends analysis berpengaruh dalam meningkatkan hasil belajar matematika. Hal ini juga didukung dengan hasil pengujian statistik $\mathrm{t}_{\text {hitung }}=2,242>\mathrm{t}_{\text {tabel }}=$ 2,000 dengan $\alpha=5 \%$, sehingga dapat diketahui bahwa terdapat pengaruh model pembelajaran means-ends analysis terhadap hasil belajar matematika.

Hasil yang diperoleh pada penelitian ini sejalan dengan penelitian yang telah dilakukan oleh Rahmadiyah (2015), yaitu setelah kedua kelas diberikan perlakuan berbeda, yakni menggunakan model means-ends analysis pada kelas eksperimen dan pembelajaran konvensional pada kelas kontrol. Hasil posttest menunjukkan bahwa kemampuan berpikir kritis matematis peserta didik yang diajar dengan model means-ends analysis lebih tinggi daripada kemampuan berpikir kritis matematis peserta didik yang diajar dengan pembelajaran konvensional, sehingga rata-rata hasil belajar kelas eksperimen juga lebih tinggi dibandingkan dengan kelas kontrol.

penelitian yang juga sejalan dengan penelitian ini adalah penelitian yang telah dilakukan oleh Okti Anggun Pasesi (2017) yang menunjukkan bahwa kemampuan pemecahan masalah matematis peserta didik pada kelas yang menerapkan model meansends analysis lebih tinggi dibandingkan dengan kelas yang menerapkan pembelajaran konvensional, sehingga hasil belajar peserta didik pada kelas eksperimen lebih tinggi dibandingkan dengan kelas kontrol. Serta penelitian Harto dkk (2015) yang menyimpulkan bahwa hasil belajar siswa dengan menggunakan model pembelajaran means-ends analysis lebih tinggi debandingkan dengan pembelajaran konvensional.

\section{PENUTUP \\ Simpulan}

Berdasarkan penelitian yang telah dilakukan di kelas VII SMP Negeri 1 Bengkulu Tengah dapat disimpulkan bahwa rata-rata hasil belajar matematika peserta didik pada kelas means-ends analysis lebih tinggi dari rata-rata hasil belajar matematika peserta didik pada kelas ekspositori

\section{Saran}

Saran yang dapat diberikan berdasarkan penelitian yang telah dilakukan di SMP Negeri 1 Bengkulu Tengah adalah Pada proses pembelajaran peserta didik seharusnya dibiasakan untuk menyelesaikan masalah melalui langkah-langkah pemecahan masalah dengan cara memperbanyak latihan soal

Apri, Agus, Effie

Perbandingan Hasil Belajar Antara Model Pembelajaran Means-Ends Analysis (MEA) Dengan Pembelajaran Ekspositori 
menggunakan langkah-langkah pemecahan masalah.

\section{DAFTAR PUSTAKA}

Hasan, Iqbal. 2008. Pokok-Pokok Materi Statistik 2 (Statistik Inferensif). Jakarta: Bumi Aksara

Huda, Miftahul. 2017. Model-Model Pengajaran dan Pembelajaran. Yogyakarta: Pustaka Pelajar.

Lestari, K. E dan Yudhanegara, M. R. 2017. Penelitian Pendidikan Matematika. Bandung: Refika Aditama.

Martono, Nanang. (2014). Metode Penelitian Kuantitatif: Analisis Isi dan Analisis Data Sekunder. Jakarta: PT RajaGrafindo Persada

Pasesi, Okti Anggun. 2017. "Pengaruh Model Pembelajaran Means-Ends Analysis (MEA) Terhadap Kemampuan Pemecahan Masalah Matematis Peserta Didik Kelas X SMA Negeri 3 Kota Bengkulu”. Skripsi tidak diterbitkan. Bengkulu: Fakultas Keguruan dan Ilmu Pendidikan Universitas Bengkulu.

Rahmadiyah. 2015. "Pengaruh Penerapan Strategi Pembelajaran Means-Ends Analysis (MEA) dalam Pembelajaran Matematika Terhadap Kemampuan Berpikir Kritis Metematis Peserta didik”. Skripsi tidak diterbitkan. Jakarta : UIN Syarif Hidayatullah Jakarta.

Shoimin, Aris. 2014. 68 Model Pembelajaran Inovatif dalam Kurikulum 2013. Yogyakarta: Ar-ruzz Media
Siregar, Syofian. 2014. Statistika Deskriptif untuk Penelitian. Jakarta: RajaGrafindo Persada.

Sugiyono. (2017). Statistika Untuk Penelitian. Bandung: Alfabeta

Harto, dkk (2014). Pengaruh Model Pembelajaran Means-Ends Analysis (MEA) Dengan Setting Belajar Kelompok Berbantuan LKS Terhadap Hasil Belajar Matematika Siswa Kelas IV DI SD Desa Bebetan. E-journal MIMBAR PGSD Universitas Pendidikan Ganesha Vol. 1 No.

(https://ejournal.undiksha.ac.id/index.ph $\mathrm{p} / \mathrm{JJPGSD} /$ article/view/2559. Diakses 3 januari 2018. 